\title{
Factors Affecting the Problem of Guidance and Counseling Service Programs in High Schools
}

\author{
Dina Rahmawati Hapsyah, Herdi Herdi \\ Universitas Negeri Jakarta \\ dinarahmawatih_bk18s2@mahasiswa.unj.ac.id
}

Submitted: 2019-08-21, Revised: 2019-09-14, Accepted: 2019-11-07

\begin{abstract}
The implementation of Guidance and Counseling services cannot be separated from various factors that can influence. The purpose of this study is to study what factors can affect the implementation of Guidance and Counseling program services in high school. This study uses descriptive research with survey methods. Data collection techniques used through the instrument contained a questionnaire. The results of the study show that the Guidance and Counseling program has been well prepared. But the implementation of Guidance and Counseling is still not good, and this is characterized by high factors that influence the implementation of Guidance and Counseling service programs. The following are the percentages obtained, among others: personal factors consisting of the competence of the counselor get a percentage of $73 \%$ according to the high category; $71 \%$ depending on the high category; homeroom teacher obtained a percentage of $79 \%$ in the high category; subject teachers earn a percentage of $75 \%$. Non-personal factors consisting of the Guidance and Counseling program obtained a percentage of 70 with a high category; Facilities and infrastructure have a percentage of $77 \%$ in the high category.
\end{abstract}

Keywords: Guidance and Counseling Program; Guidance and Counseling in High Schools; Implementation of Guidance and Counseling services

\section{Introduction}

Guidance and counseling is a way to provide help to someone or more whose goal is to achieve the optimal developmental task. This is consistent with the statement (Rahman, 2003) that guidance and counseling is assistance given to individuals from an expert or counselor who has a goal so that the individual can develop themselves and understand themselves to achieve a good life. Furthermore, the results of research from Abidin (2009) revealed that individual and group counseling could help students in growing internal and inner health in their daily lives. The effectiveness of students will be formed, both in personal, cognitive, psychomotor, and affective aspects. According to (Tohirin, 2009) Guidance and Counseling is the process of providing assistance provided to an individual (counselee) by an expert (counselor), which is done through several face-to-face meetings between the counselee and counselor. Face to face meetings conducted in the process of providing Guidance and Counseling services will involve communication skills possessed by the counselor to achieve the desired goals. These skills are the key to successful counseling implementation (Hariko, 2017). The goal is that the counselee has skills in developing themselves, looking for, and finding problems and can solve the challenges they face. Guidance and Counseling services basically have a goal that is no different from developing themselves optimally.

Individual counseling services can help students deal with problems that are personal or personal and help improve individuals. In group counseling, students will be able to grow social potential positively, effectively, productively, and collectively through group dynamics (Abidin, 2009). Implementation of Guidance and Counseling services is often considered inappropriate in the provision of services to students. It is not uncommon for some Guidance and Counseling teachers to perform functions that are not by the purpose of the program that has been made, such as the teacher only enters the class and assigns assignments to students. This can happen for some time until the service implementation is not by the program that has been well made. Implementation of this service can occur for a number of reasons, for 
example Guidance and Counseling teachers have a high workload, inadequate facilities and infrastructure for Guidance and Counseling, hours given to Guidance and Counseling are less optimal and simple, and Guidance and Counseling teachers lack understanding of how to implement good guidance and counseling services and in accordance with the objectives of the program. This study aims to find out what factors can influence the implementation of Guidance and Counseling service programs in schools.

The Guidance and Counseling program will assist teachers in implementing Guidance and Counseling services efficiently and effectively (Sari, Giyono, \& Mayasari, 2013). The Guidance and Counseling program is made in several stages, namely planning, organizing, implementing, and monitoring. Planning begins with the preparation of Guidance and Counseling service programs in the form of RPL programs, annual, semester, monthly, and daily (Sultani, 2017). The implementation of Guidance and Counseling service activities carried out by Guidance and Counseling teachers or school counselors does not always run smoothly and function properly. It can occur because of obstacles that come from the counselor himself or the counselee. Here are some of the obstacles that may arise from the counselee (Kamaruzzaman, 2016), namely:

1) The counselee is not open in expressing the problems he faces;

2) The counselee feels not free when showing the problem;

3) The atmosphere in the counseling room does not make it comfortable;

4) The counselee lacks confidence in his counselor.

Other research conducted by (Prasetyaningtyas, Sugiharto, \& Suharto, 2012) states that there are two factors of obstacles experienced in the implementation of Guidance and Counseling services, namely internal factors and external factors. Internal factors consist of counselor competency, work creativity, and work motivation. External factors include the principal, subject teachers, students' perceptions and interests, and infrastructure.

Two factors have been determined that can influence the implementation of the Guidance and Counseling program, namely internal and external factors, in this study, the researcher will divide the two factors into personal and non-personal factors. The following explanation:

1. Personal factors are factors relating to individuals in the implementation of Guidance and Counseling services in schools. In this study, personal factors involved in the implementation of the Guidance and Counseling service program in schools are given:

a. Counselor

Counselors are the main actors in the implementation of Guidance and Counseling services. Counselors are required to have various competencies and skills in counseling that must be possessed. Some things to note related to the counselor's factors are:

- Educational background for counselors

In accordance with the rules of Permendikbud no. 111 of 2014 concerning counseling guidance in elementary schools articles 1 number 3 and 4, which contain counselor education qualifications, namely: Counselors who are related educators and have minimum academic qualifications. 1) majoring in Guidance and Counseling and graduating professional education from Guidance and Counseling/counselor teachers. Guidance and Counseling teachers are teaching staff who have a minimum education qualification of a Bachelor's Degree (S-1) majoring in Guidance and Counseling and have skills in the Guidance and Counseling section.

- Counselor Competencies

Counselor is someone who provides counseling services to students, a counselor must have some competencies that must be mastered so that counselors can help students in overcoming their difficulties. Guidance and Counseling teacher competencies in this matter include pedagogical, personal, social, and professional skills. Pedagogical 
competence is about the counselor's mastery of educational concepts and practices, how to apply psychologically and physiologically to clients, addressing the core of Guidance and Counseling services in the education unit; Personal competence related to this counselor, the counselor must have faith and devotion to YME, be free to choose, uphold the values of help, and be able to display quality performance; Social competence in counselors relating to counselors has the ability and skills to collaborate between professions, implement collaboration in the workplace, have a squeeze in organizations that involve; Professional competencies that provide counselor competence in the concept of satisfaction of assessments to understand counselee needs, understand theories and practices in counseling guidance services, be able to properly support the Guidance and Counseling program plan, be able to drive the process and produce from the assistance of counseling services, assist accountability and support theory and practice in Guidance and Counseling studies.

- Counselor Performance

Competent counselors or counselors will have the ability and skills to carry out Guidance and Counseling assistance. Counselors will carry out coaching and counseling tasks with a sense of complete responsibility, and show optimal professional attitude.

b. Headmaster

The school principal involves the party responsible for the entire implementation of Guidance and Counseling services in the school. The principal is responsible for various matters responsible and counseling, including planning programs, integration programs, Guidance and Counseling support services, school administration programs, supervision of the implementation of Guidance and Counseling services, allocation of assistance and counseling information assistance, costs and facilities service compilation. Supporting Guidance and Counseling services is largely determined by the principal playing his role as supervision, coordination, and cooperation. Therefore, the principal must have knowledge about Guidance and Counseling.

c. Subject teachers

The teacher is a person who has an important task and role in providing learning to students. In Guidance and Counseling, the role and contribution of subject teachers is important, because subject teachers can help Guidance and Counseling teachers or counselors in supporting students who need services, subject teachers can help provide socialization regarding bi guidance and counseling, etc. In the end, the collaboration between the counselors and subject teachers was very good to achieve optimal guidance and counseling services in schools.

2. Non-personal factors are other factors that can influence the implementation of guidance and counseling programs in schools. Factors relating to non-individuals in the implementation of guidance and counseling programs, consisting of:

a. Program

Guidance and counseling programs are made by counseling teachers in the hope that the delay in counseling guidance services will reach the optimal goals for the growth of learners. A guidance program that has been well established; next is the implementation of the program. To receive a good program, there are several stages in program planning that must be considered, namely: 1) Analysis of student needs; 2) Determine the objectives to be achieved; 3) Analyzing Conditions and Situations in schools; 4) Determine the techniques and strategies to be used; 5) Determine school staff who will be the implementers; 6) Predict the budgetary needs and the facilities and infrastructure needed; 7) Anticipating various obstacles that will arise; 8) Estimating the time and place of implementation (Sugiyono (2008). 
The Guidance and Counseling program will contain several components that will appear in the program plan and also the program implementation. Various things must be considered when implementing a Guidance and Counseling program, according to Aqib (2012) such as:

1. The principles of administration of the guidance program, include: a) the program that will be made according to the needs or relevant to the needs of the developer and development of students; b) programs created in Guidance and Counseling can be combined in all school programs; c) each assistance and counseling have their respective roles and functions; d) the principal as the person responsible for organizing the Guidance and Counseling program; e) Guidance and Counseling program is made simple but supports its implementation; f) the Guidance and Counseling program requires an appropriate organizational structure.

2. Organizational Assistance, containing: a) the organizational pattern requested by all school staff as executors of the Guidance and Counseling assistance program; b) the organizational pattern of implementing a Guidance and Counseling service program more specifically, specifically, and at a certain time; c) organizational patterns that exist in secondary schools and are referred to as "instructor teacher programs"

b. Infrastructure

In implementing programs, services and guidance in schools, facilities and infrastructure to support the implementation of these services are needed This is by the statement (Gysbers \& P, 2012), which says that facilities and infrastructure are essential indicators in planning counseling and guidance programs. The available facilities and infrastructure will provide effective implementation of a Guidance and Counseling service program. Some of the facilities and infrastructure that can support the implementation of Guidance and Counseling services: adequate and comfortable counseling room containing Guidance and Counseling counseling, student personal books, counseling room, bookshelves, and cabinets; learning media that discusses training and counseling. Based on the regulation from Permendikbud number 111 of 2014, the Guidance and Counseling room must be adjusted to the needs of the type and amount of places. 1) Individual counseling room with workspace; 2) living room; 3) group counseling and guidance rooms; 4) data space; 5) library counseling room (bibliocounseling); and 6) other areas suitable for the development of the Guidance and Counseling profession. The research objective is to see what factors can influence the implementation of the program.

\section{Methods}

The research method used in this study is a survey method, namely research that takes samples from participants and uses a questionnaire as the main data collection tool. The sampling technique in this study uses saturated samples, which uses the entire population as a research sample.

This research was conducted by conducting a survey in several secondary schools in Lampung, including: 1) SMA N 9 Bandar Lampung; 2) SMA N 1 Terbanggi; 3) MA Banjit Right Way; 4) SMA N 2 Natar; 5) Swadhipha Natar High School; 6) SMA N 1 Sidomulyo, South Lampung; 7) SMA N 1 Tanjung Raya Mesuji; 8) MA Nurul Ulum, Central Lampung. In this study, researchers used an instrument developed by Siti Rahmawati. This instrument was prepared and developed based on factors that influence the implementation of the Guidance and Counseling program in schools, namely personal factors consisting of: 1) School counselors; 2) Principal; 3) Subject Teachers; 4) Protective class. Non-personal factors which contain: 1) Guidance and Counseling programs; 2) Facilities and infrastructure. 
This instrument consists of 66 items that state and use a Likert scale to see factors that can be applied to the Guidance and Counseling program in secondary schools.

\section{Results and Discussion}

Based on the results of research on the Factors that Influence the implementation of the Guidance and Counseling Service Program in high school that has been carried out by researchers, it can be given in diagram 1 (Factors affecting the implementation of services):

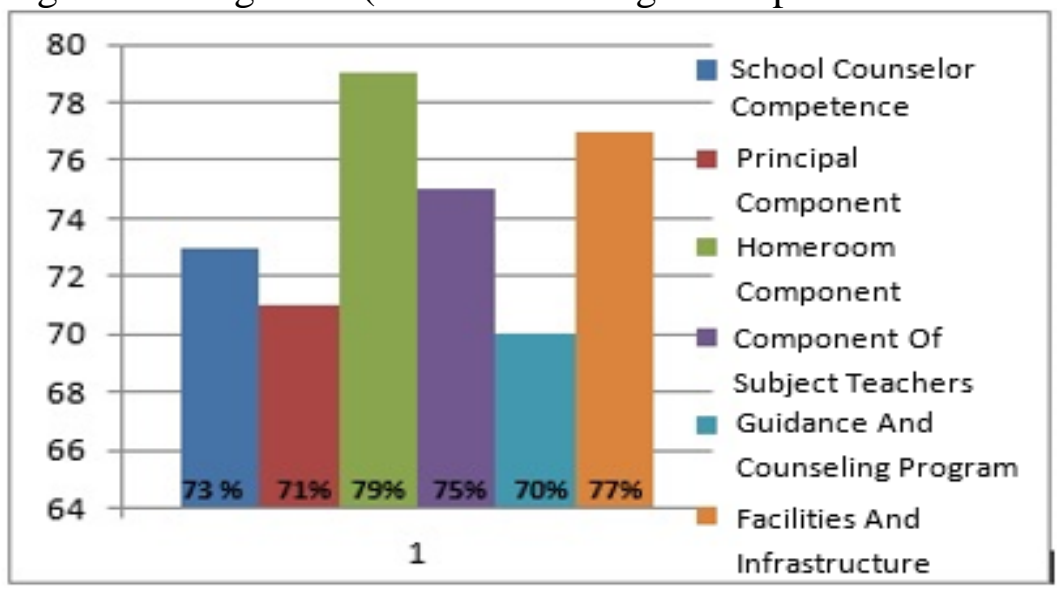

Figure 1. (Factors Affecting Service Implementation)

Based on figure 1 can be seen in fact, the number of factors that are owned, which is greater than the implementation of the program, guidance and counseling. The top six factors are in the high category because the differences are different. Personal factors are the most decisive factors as a factor in implementing Guidance and Counseling programs compared to non-personal factors. The highest component of personal factors is guardian class with a percentage of $79 \%$ while non-personal factors are facilities and infrastructure with a percentage of $77 \%$.

\section{Faktor Personal}

In the diagram above, it can be seen as a personal factor that influences the implementation of counseling and guidance programs. There are 4 personal factors including:

1) School counselors with a percentage of $73 \%$ with a high category. This means that counselors in making programs and implementing services are still less than optimal and less optimal in their implementation. The results are relevant to research conducted by (Kamaruzzaman, 2016) regarding the analysis of inhibiting factors for Guidance and Counseling teacher performance in schools, Guidance and Counseling teacher competence in schools is still low, with a percentage of $25.9 \%$, personality and dedication of only $20.8 \%$, and decoration behind education by $32 \%$. In this component, there are 3 indicators used, including: professional competence, social competence, and their respective assignments. With each percentage:

Table 1. Percentage of Counselor Competencies

\begin{tabular}{ccc}
\hline Indicator & Percentage & Category \\
\hline $\begin{array}{c}\text { Professional } \\
\text { Competence }\end{array}$ & $69 \%$ & High \\
$\begin{array}{c}\text { Social } \\
\text { Competence }\end{array}$ & $78 \%$ & High \\
$\begin{array}{c}\text { Execution of } \\
\text { Tasks }\end{array}$ & $73 \%$ & High \\
\hline
\end{tabular}


2) Principal with a percentage of $71 \%$ with a high category. There are three indicators used in the principal component, including: tasks, responsibilities, and roles. The principal is responsible for a number of matters relating to Guidance and Counseling, including: planning programs, integration programs, Guidance and Counseling programs, administration of school programs, supervision of the implementation of Guidance and Counseling services, allocation of assistance programs for the delivery of assistance and counseling, and costs accompanied facilities in the implementation of services. The results are relevant to the descriptive study conducted by (Kholilah \& Khusumadewi, 2018) regarding the implementation of Guidance and Counseling services in schools, this study shows inhibiting factors in the implementation of Guidance and Counseling services in schools related to class entry jam for Guidance and Counseling teachers or schedule clashing with eyes Other lessons, the workload of Guidance and Counseling teachers is too high, and good cooperation with student guardians has not been carried out optimally.

Table 2. Percentage of Principal Competency

\begin{tabular}{ccc}
\hline $\begin{array}{c}\text { Principal } \\
\text { Indicator }\end{array}$ & Percentage & Category \\
\hline Task & $77 \%$ & High \\
Responsible & $76 \%$ & High \\
Role & $65 \%$ & High \\
\hline
\end{tabular}

Related to the principal in the activities of Guidance and Counseling is not optimal in carrying out their duties, roles and responsibilities.

3) Guardian class with the highest percentage of $79 \%$ based on personal factors with a high category, meaning that the guardian class is still not maximized in collaborating with counseling teachers in counseling and counseling activities. The results of research conducted by (Fariani, Nita, \& Usman, 2017) about the role of the homeroom teacher in the implementation of Guidance and Counseling services explained that there are 5 roles performed by the homeroom teacher, namely: 1) the homeroom teacher helps the Guidance and Counseling teacher to help his work in class; 2) help Guidance and Counseling teachers to carry out their roles; 3 ) provide opportunities for students to take the Guidance and Counseling service; 4) approve actively in the activities of guidance and counseling; 5) hand over to Guidance and Counseling teachers if students need Guidance and Counseling services.

4) Teachers with a percentage of $75 \%$ are in the high category, meaning that the teacher is still not maximized, but compared to the guardian class, the teacher can still collaborate well, collaborate, and coordinate with Guidance and Counseling teachers in the implementation of Guidance and Counseling services.

\section{Non-Personal Factors}

Non-personal factors are factors relating to individuals in program planning and the implementation of Guidance and Counseling activities. In this case, there are two nonpersonal factors, namely:

1) Program Guidance and Counseling with a percentage of $70 \%$ in the high category. This shows that the Guidance and Counseling program is not yet relevant to the needs of students' development tasks. In this component there are 3 indicators that are used, among others: compiling the program, running the program, and evaluating the program with each percentage: 
Table 3. Program Percentage Relevance of Guidance and Counseling

\begin{tabular}{ccc}
\hline $\begin{array}{c}\text { Principal } \\
\text { Indicator }\end{array}$ & Percentage & Category \\
\hline $\begin{array}{c}\text { Drafting } \\
\text { Program }\end{array}$ & $80 \%$ & High \\
$\begin{array}{c}\text { Implementation } \\
\text { Program } \\
\text { Evaluation } \\
\text { Program }\end{array}$ & $60 \%$ & High \\
\hline
\end{tabular}

2) Facilities and infrastructure with the highest percentage on non-personal factors are $77 \%$ with a high category. In line with the descriptive study conducted by (Putranti, 2015), all schools have adequate Guidance and Counseling space and the cost is an interesting challenge in this regard.

This shows that in the program and implementation and counseling is still not optimal in terms of existing facilities and infrastructure, or in getting the facilities and infrastructure needed by the counselor is still difficult to obtain. In line with research conducted by Bhakti (2017), not all schools have adequate facilities and infrastructure, such as administrative rooms, guidance and group counseling rooms, and individual counseling rooms. Based on the 2014 Ministry of Education and Culture Regulation number 111 article 6 paragraph 4 and 5 on Guidance and Counseling services, it is carried out in 2 hours per week and is not only focused on activities in the classroom, but also conducted outside the classroom. The results of research conducted by Zahara (2017) show a significant positive relationship regarding Guidance and Counseling facilities and infrastructure with the priority of Guidance and Counseling services. This shows that to support the implementation of the Guidance and Counseling services, facilities and infrastructure must be given more attention. In addition, Susilowati's research (2014) shows that the level of student satisfaction with Guidance and Counseling services in aspects of supporting facilities is only $10 \%$. These percentages are referred to in fact. Appropriate support facilities.

\section{Conclusions and Suggestions}

Based on the research results it can be concluded that the Guidance and Counseling program is well made. However, the implementation of Guidance and Counseling is still not good, this is indicated by the high factors that influence the implementation of the Guidance and Counseling service program. The following are the results of the research obtained, among others: personal factors consisting of aspects of the counselor's competence; aspects of the principal, aspects of the homeroom teacher, and aspects of the subject depending on the high category. Non-personal factors consisting of aspects of the Guidance and Counseling program, aspects of facilities and infrastructure depend on the high category.

With the existence of this research, the author asks the help of teachers and school counselors with counseling assignments. Preparation programs and preparations in accordance with the needs of students' development tasks. The principal and teachers and homeroom teachers invited him to have openness in collaborating and collaborating in providing Guidance and Counseling assistance to help students develop growth and solve natural problems. 


\section{References}

Abidin, Z. (2009, Januari). Optimalisasi Konseling Individu dan Kelompok untuk Keberhasilan Siswa. Jurnal Insania, XIV(1), 132-148.

Apriatama, D. (2018, September). Faktor-Faktor Yang Menghambat Siswa Dalam Memanfaatkan Layanan Informasi Karir Di SMP Negeri 6 Palangkaraya. Juenal Bimbingan dan Konseling Indonesia, III(2), 43-48.

Aqib, Z. (2012). Ikhtisar Bimbingan \& Konseling di Sekolah. Bandung: Yrama Widya.

Bhakti, C. P. (2017). Ketersediaan Sarana Dan Prasarana Bimbingan Dan Konseling Di Sekolah Menengah Di Kabupaten Gunungkidul. Jurnal Pendidikan (Teori dan Praktik), II(2), 100-104.

Fariani, E., Nita, R. W., \& Usman, C. I. (2017). Peran Wali Kelas Dalam Layanan Bimbingan Dan Konseling Di Kelas VIII SMP Negeri 29 Padang. Jurnal Ilmiah Mahasiswa STKIP PGRI Sumbar, 1-9.

Gysbers, N., \& P, H. (2012). Developing And Managing Your School Guidance And Counseling Program Fourth Edition. Alexandria: American Counseling Assosiation.

Hariko, R. (2017). Landasan Filosofis Keterampilan Komunikasi Konseling. Jurnal Kajian Bimbingan dan Konseling, II(2), 41-49.

Juntika. (2005). Strategi Layanan Bimbingan Dan Konseling. Bandung: Refika Aditama.

Kamaruzzaman. (2016, Desember). Analisis Faktor Penghambat Kinerja Guru Bimbingan Dan Konseling Sekolah Menengah Atas. Sosial Horizon : Jurnal Pendidikan Sosial, III(2), 229-242.

Kholilah, N., \& Khusumadewi, A. (2018). Implementasi Layanan Bimbingan dan Konseling di Sekolah Dasar Islam Terpadu At-Taqwa Surabaya. Jurnal BK Unesa, 36-49.

Kurniawan, L. (2015, Juni). Pengembangan Program Layanan Bimbingan Dan Konseling Komprehensif Di SMA. Jurnal Psikologi Pendidikan \& Konseling, I(1), 1-8.

Lestari, M., Wibowo, M. E., \& Supriyo. (2013, Juni). Kompetensi Profesional Guru Bimbingan Dan Konseling Dalam Pelaksanaan Pelayanan Bimbingan Dan Konseling. Indonesian Journal Of Guidance And Counseling : Theory And Application, II(4), 1724.

Mahanggi, D. R., Nusantoro, E., \& Kurniawan, K. (2014, April). Kebijakan Kepala Sekolah Terhadap Pelayanan Bimbingan dan Konseling di SMA Negeri Se-Kabupaten Purbalingga. Indonesial Journal Of Guidance And Counseling : Tehory and Application, II(1), 49-56. 
Prasetyaningtyas, N., Sugiharto, D., \& Suharto. (2012, Desember). Hambatan Pelayanan BK di Luar Jam Pelajaran dan Upaya Mengatasinya Di SMA Kabupaten Bebes. Indonesian Journal Of Guidance And Counseling : Theory And Application, I(2), 2427.

Putranti, D. (2015). Studi Deskriptif Tentang Sarana dan Prasarana Bimbingan dan Konseling di Sekolah Menengah Pertama. Psikopedagogia, IV(1), 45-50.

Rahman, H. (2003). Bimbingan dan Konseling Pola 17. Yogyakarta: UCY Press.

Rahmawati, S. (2012). Faktor Determinan Kesenjangan Antara Program Bimbingan Konseling Dan Pelaksanaannya Di SMP Negeri Se-Kota Semaranh. Semarang: Skripsi.

Sari, E. R., Giyono, \& Mayasari, S. (2013). Faktor Penghambat Pelaksanaan Program Bimbingan Dan Konseling. ALIBKIN, 1-12.

Sugiyono. (2013). Metode Penelitian Pendidikan Pendekatan Kuantitatif, Kulaitatif, dan $R \& D$. Bandung: Alfabeta.

Sugiyono, K. K. (2008). Penyusunan Program Dan Penilaian Bimbingan Dan Konseling Di Sekolah. BK FIP UNNES.

Sukardi, D. K. (2008). Pengantar Pelaksanaan Program Bimbingan Dan Konseling. Jakarta: Rineka Cipta.

Sultani, D. I. (2017). Manajemen Bimbingan Konseling Di Smp Negeri Satu Batang Kuis Deli Serdang. Jurnal Penelitian Pendidikan Sosial Humaniora, II(2), 257-264.

Susilowati, A. (2014, Juni). Kepuasan Siswa Terhadap Layanan Bimbingan Dan Konseling Di SMKN 1 Badegan Ponorogo. Jurnal Hisbah, XI(1), 145-162.

Sutanti, T. (2015). Pelaksanaan Layanan Konseling Kelompok Pada Siswa Cerdas Istimewa Di SMA Negeri Kota Yogyakarta. Jurnal Konseling Gusjigang, I(1), 2-16.

Tohirin. (2009). Bimbingan Dan Konseling Di Sekolah Dan Madrasah (Berbasis Integrasi). Jakarta: Rajawali Pers.

Zahara, C. I. (2017, Juni). HubunganPersepsi Siswa terhadap Konselor dan Sarana Prasarana Bimbingan Konseling dengan Minat Layanan Konseling di SMP Negeri 2 Dewantara Kabupaten Aceh Utara. Analitika, IX(1), 10-20. 
